\title{
2018 年香港日本語学習者背景調査 \\ The 2018 Survey of Japanese Language Learners in Hong Kong
}

\section{斎藤誠、梁安玉、劉䃇志、李澤森、李夢娟 香港日本語教育研究会}

\section{要旨}

2010 年から実施している香港の日本語学習者背景調査では、学習目的・動機 （木山 2011、宇田川 2015、山下 2016、2018）、年少者調査（山下 2017）、日本語 学習者減少の要因調査（宇田川 2013、2014）など実施してきたが、本調査では、 JLPT 受験者を対象に香港の日本語学習者の学習上達実感度、学習スタイルを調査 するとともに、独学者に見られる特徵の一端を明らかにすることを試みた。その 結果、上達実感度では、受容能力の上達は、産出・やり取りよりも上達を実感して いること、独学者は「聞く」以外の能力の上達実感度が全体より低いことが分かった。 また、学習スタイルについては実用的で挑戦的な方法を好みながら、同時に規則 性、論理的分析をする傾向も見られ、多様な学びのスタイルが共存していることが 明らかになったが、独学者に顕著な特徵は見出されなかった。

キーワード：自己評価、上達実感度、学習スタイル、独学者 


\section{8 年香港日本語学習者背景調査}

\section{斎藤誠、梁安玉、劉礪志、李澤森、李夢娟 \\ 香港日本語教育研究会}

\section{1.はじめに}

2015 年時点の香港の日本語教育機関で学習する人数は 22,613 人（国際交流基金 2015）であるが、国際交流基金・電通（2016）は、香港での日本語学習経験者の 割合は人口の 9.7\%で、計算上 35～52 万人（2014 年の人口統計）と推定している。 この推計は、教育機関以外で学ぶ日本語学習者がかなり存在していることを示唆 している。香港日本語教育研究会（以下、研究会）が香港・マカオで実施団体と して年 2 回運営している日本語能力試験（以下、JLPT）には、日本語教育機関で の学習者（以下、機関学習者）のみならず、独学者も多く受験に来る。香港で日本 語を学ぶ大学生の学習者ビリーフ、学習スタイルを調查した板井（2000、2001、 2002）は、香港の日本語教育は「伝統的な学習・教授法が行なわれている」（板井 2001:81）が、学習者の学習スタイルは「すべての言葉や概念がわからなくても コミュニケーションを楽しむ」が、一方「ものごとの細部にこだわり、全体像を つかむのが苦手」（板井 2002:69）という相反する特徴を併せ持っていると分析 している。グローバル化が進み、外国語学習の環境が急激に変化している現在、 香港の日本語学習者の学習スタイルに変化はあるのだろうか。また、クラス活動は 学習者の日本語力向上にどの程度貢献しているのだろうか。本稿では、JLPT 受験 者を対象に香港の日本語学習者の学習上達実感度、学習スタイルを調査すると ともに、独学者に見られる特徵の一端を明らかにすることを試みた。

\section{2. 先行研究}

\section{1 学習スタイル}

学習スタイル理論では Kolb（1984）の学習理論「Experimental Learning Theory (以下、ELT)」が多く参考にされており、藤田（2002）は、これを基に日本人大学 生を対象に学習スタイルの調査を行い、5つの因子に類型化した。ELTに基づき 開発された学習スタイル調査票は「The Learning Style Inventory（以下、LSI）」(Kolb, 1999)、その問題点を修正して、Honey と Munford が作成した「Learning System Questionnaire（以下、LSQ）」（Honey \& Munford, 1995）などがあるが、藤田（2002） は日本人学習者向けに内容を修正した調査票で調査した。

Kolb（1984）の ELT は学習段階を 4 段階に分類している。まず初めに具体的に 経験する「具体的経験」、経験を内省して観察する「内省的観察」、理論や抽象的 概念の構築をする「抽象的概念化」、最後に実験を通して実証する「能動的実験」 
である。藤田（2002）は LSI も LSQ もこれら 4 極が対極にあり、正負の関係にある としているが、日本人大学生を対象にした調查の結果「熟考」「論理」「実用」「挑 戦」「秩序」の 5 つの因子が抽出され、互い正負ではなく、相関関係にあることを 明らかにした。岡田（2012）では、前述 5 因子に「感覚」の因子を加え、6 類型 に分類している。

\section{2 香港における学習スタイル調査}

香港の日本語学習者の学習スタイル研究については、板井（2002）がある。 香港の学習者は「視覚型」(本やビデオなど視覚的手段を用いるとよく学べる)、 「操作型」(プロジェクト、ゲーム、実験など教室を移動しながら学ぶのを好む) の傾向が強く、「聴覚型」（討論、ロールプレイ、講義など聞いたり話したりする 活動）は低いとの結果を報告している。

板井（2001）で行った香港 4 大学の大学生を対象にした学習ストラテジーと ビリーフ調查でも、同様の結果を明らかにし、香港の日本語学習者は「学習動機が 個人的で高く、クラスで話すことにアレルギーは感じていない（板井 2001:92）」 こと、伝統的教授法（例：文法学習）を比較的好むが、同時にクラス活動では教師 に「コミュニカティブ」で「多くのアクティビティを行うべきだ（板井 2001:92）」 と思っていると分析した。これらの調查は大学生を対象にしており、香港で最も 割合の高い語学学校での学習者や独学者は対象になっていない。宇田川（2015） も香港日本語学習者（JLPT N3〜 5 受験者）のビリーフ調査を行い、香港の日本語 学習者は「話す」ことに積極性を持っているなど、板井（2001）に近い結果を 報告している。

瀬尾 (2013) は民間日本語学校で学ぶ 10 代の日本語学習者への質的研究で、個々 の学習者が従来の知識伝達型の教育方法よりも、主体的に学習活動に参加し、 彼らがおかれている状況（アニメ・漫画・ゲーム・テレビ番組など身近にある 日本語リソース) に依存した中で知識を獲得し、相互作用によって学習が行われて いる実態を明らかにしている。

香港における日本語学習者で、独学者を対象にした調査では、国際交流基金・ 電通（2016）にて調查対象に含まれている。これには日本語学習経験者のうち 独学者の占める割合から、香港の人口に占める推定独習者人口（香港の人口の 約 9.7\%) は示されているが、学習経験、学習方法などは全体の学習経験者の数值 のみで、独学者のデータは公表されていない。 


\section{3. 目的}

本調查の目的は、以下の 2 点を明らかにすることである。

1）香港の学習者は自分の日本語の上達について、技能別にどう感じているの か。学習環境により違いがあるのか。

2）香港の日本語学習者の学習スタイルの傾向を明らかにする。また、独学者 ${ }^{1}$ の特徵はあるのかどうか。

\section{4. 調查方法・調査協力者について}

\section{1 調查方法}

対象者：2018 年 6 月、11 月に研究会が実施した JLPT 応募者（N4、N5）を対象 とした学習者調査に協力をいただいた方。

調査方法：調査協力者に質問用紙を配布し、記入したものを研究会担当者が 回収した。回答形式は主に選択式（「その他」欄は自由記述形式）。 質問用紙は中国語（繁体字）で作成したものを配布した。

集計方法：表計算ソフトにデータ入力した。なお、中国語で書かれた自由記述 箇所は日本語に訳した。

\section{2 調查協力者の基本情報}

調査協力者は 6 月 399 人（N4 235 人、N5 164 人）、11月 384 人（N4 223 人、 N5 161 人）の計 783 人である。年齢別の内訳は表 1 の通りである。今回の調査協力 者は 20～30 歳代が多くを占めている。表 2 の職業を見ると、社会人が過半数を 占め、高等教育機関の学生が 3 分の 1 強となっている。

表 3 日本語学習歴では、N4・N5 協力者とも 1 年以上 2 年未満が最も多く、N4 は次いで 2 年以上 3 年未満、N5 は半年以上 1 年未満となっており、N4 協力者は 半年〜3 年未満、N5 協力者は 2 年未満が多数を占めている。

本項における独学者とは、調査票で通っている教育機関に回答せず、「独学」にマークした 協力者を指す。調査では複数回答を可としたので、教育機関に通いながら独学でも学習 している人も多数いたが、5.調査内容・結果での全体、機関学習者との比較では、教育 機関に通わない人のみを独学者として抽出した。 
表 1 レベル別年齢

\begin{tabular}{|c|c|c|c|c|c|c|c|c|}
\hline & \multicolumn{4}{|l|}{$\mathrm{N} 4$} & \multicolumn{4}{|l|}{ N5 } \\
\hline & 6 月 & 11 月 & 計 & $\%$ & 6 月 & 11 月 & 計 & $\%$ \\
\hline a.11 歳以下 & 1 & 0 & 1 & 0.2 & 1 & 0 & 1 & 0.3 \\
\hline b. $12 \sim 17$ 歳 & 18 & 14 & 32 & 7.0 & 9 & 5 & 14 & 4.3 \\
\hline c. $18 \sim 22$ 歳 & 52 & 44 & 96 & 21.0 & 31 & 38 & 69 & 21.2 \\
\hline d.23〜29 歳 & 93 & 77 & 170 & 37.1 & 52 & 59 & 111 & 34.2 \\
\hline e. $30 \sim 39$ 歳 & 51 & 57 & 108 & 23.6 & 42 & 37 & 79 & 24.3 \\
\hline f. $40 \sim 49$ 歳 & 16 & 18 & 34 & 7.4 & 20 & 9 & 29 & 8.9 \\
\hline g. $50 \sim 59$ 歳 & 4 & 10 & 14 & 3.1 & 7 & 8 & 15 & 4.6 \\
\hline h. $60 \sim 69$ 歳 & 0 & 3 & 3 & 0.7 & 1 & 4 & 5 & 1.5 \\
\hline i. 70 歳以上 & 0 & 0 & 0 & $\mathbf{0}$ & 1 & 0 & 1 & 0.3 \\
\hline 不明 & 0 & 0 & 0 & $\mathbf{0}$ & 0 & 1 & 1 & 0.3 \\
\hline 計 & 235 & 223 & 458 & & 164 & 161 & 325 & \\
\hline 総計 & \multicolumn{8}{|l|}{783} \\
\hline
\end{tabular}

表 2 レベル別職業

\begin{tabular}{|l|l|l|l|l|l|l|}
\hline & \multicolumn{3}{|l|}{$\mathrm{N} 4$} & $\mathrm{~N} 5$ & \multicolumn{2}{l|}{ 計 } \\
\hline & 人 & $\%$ & $人$ & $\%$ & 人 & $\%$ \\
\hline a.小・中・高生 & $\mathbf{3 7}$ & $\mathbf{8 . 0}$ & $\mathbf{1 7}$ & $\mathbf{5 . 2}$ & $\mathbf{5 4}$ & $\mathbf{6 . 9}$ \\
\hline b. 短大 $($ 副学士 AD・HD) & $\mathbf{2 9}$ & $\mathbf{6 . 3}$ & $\mathbf{2 5}$ & $\mathbf{7 . 7}$ & $\mathbf{5 4}$ & $\mathbf{6 . 9}$ \\
\hline c. 大学生 & $\mathbf{1 2 1}$ & $\mathbf{2 6 . 4}$ & $\mathbf{7 8}$ & $\mathbf{2 4 . 0}$ & $\mathbf{1 9 9}$ & $\mathbf{2 5 . 4}$ \\
\hline d. 大学院生 $(\mathrm{MA}, \mathrm{Dr})$ & $\mathbf{2 1}$ & $\mathbf{4 . 6}$ & $\mathbf{1 2}$ & $\mathbf{3 . 7}$ & $\mathbf{3 3}$ & $\mathbf{4 . 2}$ \\
\hline e. 就労、会社員 & $\mathbf{2 3 9}$ & $\mathbf{5 2 . 2}$ & $\mathbf{1 7 9}$ & $\mathbf{5 5 . 1}$ & $\mathbf{4 1 8}$ & $\mathbf{5 3 . 4}$ \\
\hline f. 年金生活者 & $\mathbf{7}$ & $\mathbf{1 . 5}$ & $\mathbf{7}$ & $\mathbf{2 . 2}$ & $\mathbf{1 4}$ & $\mathbf{1 . 8}$ \\
\hline g. その他 & $\mathbf{4}$ & $\mathbf{0 . 9}$ & $\mathbf{7}$ & $\mathbf{2 . 2}$ & $\mathbf{1 1}$ & $\mathbf{1 . 4}$ \\
\hline
\end{tabular}


2018 年香港日本語学習者背景調査

表 3 レベル別日本語学習歴

\begin{tabular}{|c|c|c|c|c|c|c|}
\hline & \multicolumn{2}{|l|}{ N4 } & \multicolumn{2}{|l|}{ N5 } & \multicolumn{2}{|l|}{ 計 } \\
\hline & 人 & $\%$ & 人 & $\%$ & 人 & $\%$ \\
\hline a.半年未満 & 32 & 7.0 & 49 & 15.1 & 79 & 10.1 \\
\hline b. 半年 1 年未満 & 71 & 15.5 & 100 & 30.8 & 171 & 21.8 \\
\hline c. 1 年～ 2 年未満 & 205 & 44.6 & 151 & 46.7 & 356 & 45.5 \\
\hline d. 2 年〜 3 年末満 & 107 & 23.4 & 20 & 6.2 & 127 & 16.2 \\
\hline e. 3 年～4 年未満 & 20 & 4.4 & $\mathbf{0}$ & 0.0 & 20 & 25.6 \\
\hline $\mathrm{f} .3$ 年 $\sim 4$ 年未満 & 10 & 2.2 & 1 & 0.3 & 11 & 14.0 \\
\hline g. 5 年以上 & 13 & 2.8 & 4 & 0.1 & 17 & 2.2 \\
\hline
\end{tabular}

表 4 学習環境（教育機関等）については、複数の教育機関に通っている人、機関 と個人授業など、複数の場で学ぶ人もいると想定されるため、複数回答可とした。 割合では、民間日本語学校で学習している人と、独学者の割合が高い。国際交流 基金・電通（2016）では、独学のみで機関で学習していない学習者の割合が $29.4 \%$ とあるが、本調査での同割合は $22.7 \%$ ある。

表 4 レベル別学習環境（教育機関等）

\begin{tabular}{|c|c|c|c|c|c|c|c|c|}
\hline & \multicolumn{4}{|l|}{ N4 } & \multicolumn{4}{|l|}{ N5 } \\
\hline & 6 月 & 11 月 & 計 & $\%$ & 6 月 & 11 月 & 計 & $\%$ \\
\hline a.小学校 & 0 & 0 & $\mathbf{0}$ & $\mathbf{0}$ & 0 & 0 & $\mathbf{0}$ & $\mathbf{0}$ \\
\hline b.中・高校 & 2 & 0 & 2 & 0.4 & 2 & 1 & 3 & 0.9 \\
\hline c.副学士（AD/HD） & 3 & 2 & 5 & 1.1 & 2 & 3 & 5 & 1.5 \\
\hline d. 大学・大学院の主/副専攻 & 3 & 11 & 14 & 3.1 & 3 & 2 & 5 & 1.5 \\
\hline e.大学の選択科目 & 3 & 6 & 9 & 2.0 & 3 & 3 & 6 & 1.8 \\
\hline f.大学付属機関 - 社会人講座 & 20 & 20 & 40 & 8.7 & 10 & 21 & 31 & 9.5 \\
\hline g.語学学校（民間） & 114 & 117 & 231 & 50.4 & 111 & 104 & 215 & 66.2 \\
\hline h.個人授業 & 20 & 16 & 36 & 7.9 & 9 & 4 & 13 & 4.0 \\
\hline i.独学（本で学習） & 94 & 70 & 164 & 35.8 & 36 & 35 & 71 & 21.8 \\
\hline $\begin{array}{l}\mathrm{j} . \text { 独学 (ネットなど IT } \\
\text { 環境で学習) }\end{array}$ & 59 & 57 & 116 & 25.3 & 21 & 22 & 43 & 13.2 \\
\hline k. 通信教育 & 1 & 1 & 2 & 0.4 & 0 & 1 & 1 & 0.3 \\
\hline 1.今は勉強していない & 5 & 4 & 9 & 2.0 & 7 & 3 & 10 & 3.1 \\
\hline m.その他 & 2 & 0 & 2 & 0.4 & 1 & 1 & 2 & 0.6 \\
\hline
\end{tabular}


日本語学習の目標を質問したところ、表 5 の通り上位には比較的短期間で達成 できる目標が高い割合を占め、「留学・生活したい」「仕事がしたい」「議論ができる ようになりたい」など比較的高度なレベルを目標にしている人は 4 割程度である ことが分かった。これは木山他（2011）、宇田川他（2014）、山下他（2016、2018） の学習目的・意義を調査した結果と共通している。

\section{表 5 日本語学習の目標}

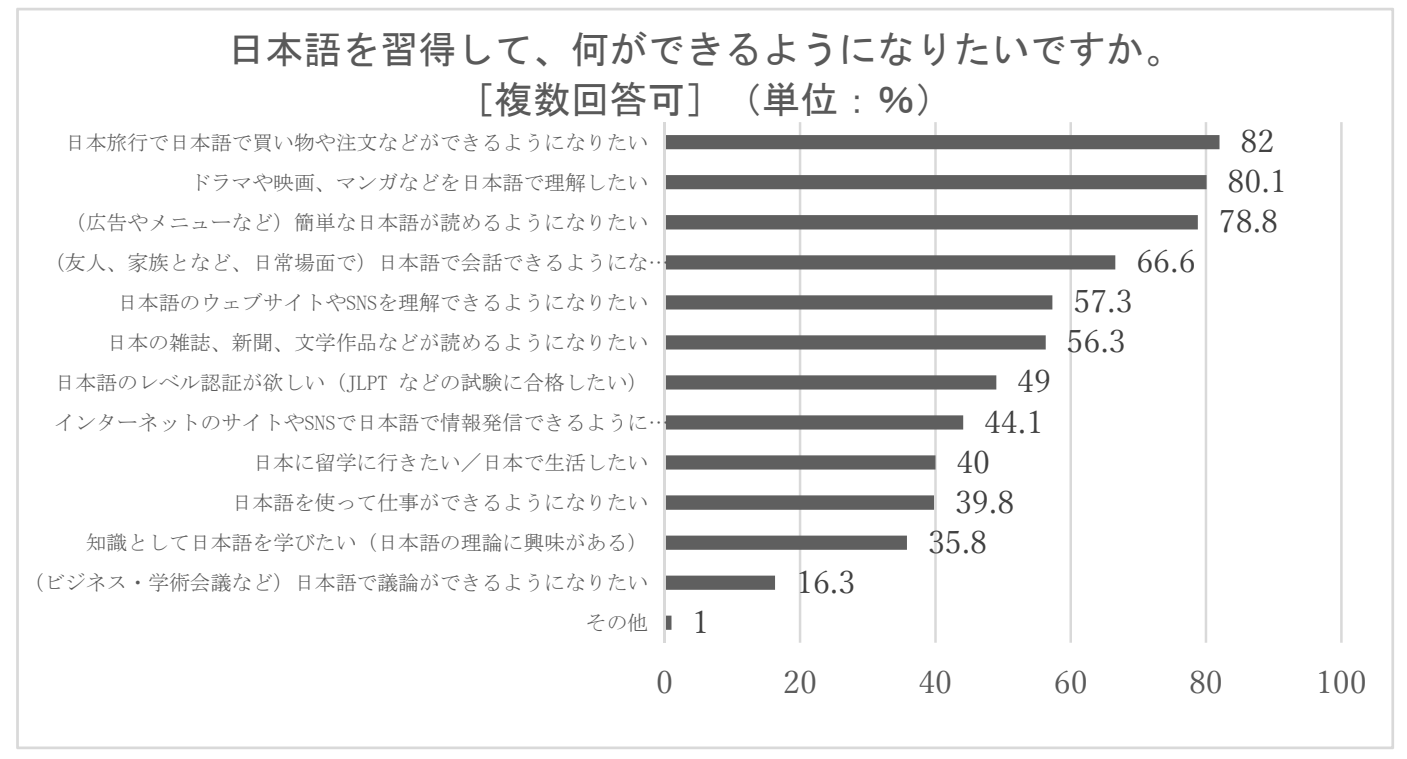

\section{5. 調査内容 - 結果}

\section{1 上達実感度}

宇田川他（2015）は、香港の日本語学習者が「読む」「書く」「聴く」「会話」「単 独で話す」のうち伸ばしたい日本語能力を調查したところ、「会話」が最も多く $43 \%$ を占め、口頭コミュニケーションに関わる能力を伸ばしたい人が合計 $83.6 \%$ に上ったことを報告している。

今回の調査では、上達を実感しているかどうか、自己評価をしてもらった。表 6-1 によると、全体的に N5 より N4 の方がわずかに上達を実感している傾向が わかる。瀬尾（2011） も日本語学習が初級のうちに困難さを抱え、レベルが上が るにつれて学習の喜びを感じている実態を明らかにしている。一方、技能別に見 ると、「受容」能力（1、2）の実感度が全体平均で 3.77、3.10 と比較的実感して いる。特に「読解」能力の実感度が高く、標準偏差も 0.76 と偏りが少ない。それ に対して、3、4の「産出」能力、5の「やりとり」スキルの実感度は「受容」に 比べ低い結果となった。ただし、標準偏差が 1 に近いかそれ以上であり、上達を 実感する人とそうでない人の差も大きいことが考えられる。 
表 6-1 日本語能力上達の実感度 ${ }^{2}$

\begin{tabular}{|c|c|c|c|c|c|}
\hline & 上達を実感したこと & N4 平均 & N5 平均 & 全体 & 標準偏差 \\
\hline 1 & 日本語の文章が読めるようになった & 3.83 & 3.70 & 3.77 & 0.76 \\
\hline 2 & 日本語の会話が聞けるようになった & 3.12 & 3.07 & 3.10 & 0.96 \\
\hline 3 & 日本語で文章が書けるようになった & 2.56 & 2.50 & 2.54 & 1.06 \\
\hline 4 & $\begin{array}{l}\text { 日本語で言いたいことを伝えられる } \\
\text { ようになった }\end{array}$ & 2.81 & 2.79 & 2.80 & 0.99 \\
\hline 5 & $\begin{array}{l}\text { 日本語で会話（やりとり）ができる } \\
\text { ようになった }\end{array}$ & 2.62 & 2.54 & 2.59 & 1.06 \\
\hline
\end{tabular}

次に、独学者 $(279$ 人 $)$ と機関学習者 ${ }^{3}(533$ 人) を比較したところ、 2 のみ独学 者の方の上達実感度が高いという結果になった（表 6-2 参照）。ちなみに、独学 者の学習方法も調查しており、「アニメ・動画・映画を視聴 $(75.5 \%) 」 、 「($ 有料・ 無料の) e ラーニング講座・コンテンツで学ぶ」 $(49.6 \%) 、 「$ 音楽を聴く $(48.6 \%)$ 、

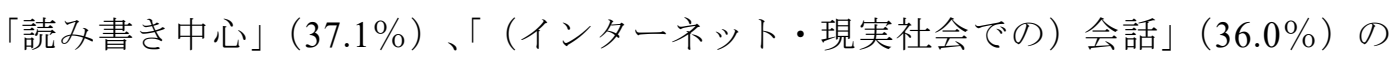
順に多く、耳から学ぶ方法を多数取り入れていることがわかった。なお、チャット

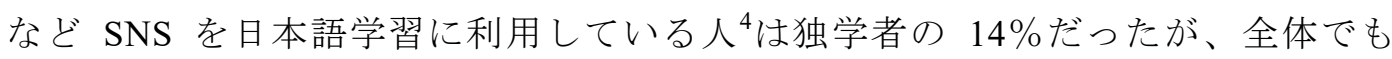
$14 \%$ と割合は変わらなかった。

\section{表 6-2 独学者と機関学習者の日本語能力上達の実感度比較}

\begin{tabular}{|l|l|c|c|}
\hline & 上達を実感したこと & 独学者 & 機関学習者 \\
\hline 1 & 日本語の文章が読めるようになった & 3.58 & 3.81 \\
\hline 2 & 日本語の会話が聞けるようになった & 3.14 & 3.09 \\
\hline 3 & 日本語で文章が書けるようになった & 2.10 & 2.61 \\
\hline 4 & 日本語で言いたいことを伝えられるようになった & 2.60 & 2.83 \\
\hline 5 & 日本語で会話 (やりとり) ができるようになった & 2.57 & 2.58 \\
\hline
\end{tabular}

2 次の選択肢から当てはまるものを 1 つ回答してもらった。5: 非常によく実感する 4 : 実感 寸る 3: 多少実感する 2: どちらかというとあまり実感しない 1 : 実感しない 0 : 全く 実感しない

3 表 4 の $\sim \mathrm{g}$ 回答者を「機関学習者」とした。複数回答している人がいるため、総数は合致 しない。

4 例えば村上（2018）は、独学者が外国語学習にSNS を活用している事例を紹介している。 


\section{2 香港における日本語学習者の学習スタイル}

質問項目と学習スタイルの分類型は、藤田（2002）及び岡田（2011）に基づき、 香港の日本語学習者への調查に適していると思われる質問を選択した。また、 香港の学習者像を調查するため、クラス活動の好みを調查する項目を追加した。 それは、教師の説明を聞き、受け身型の授業を好む「7 座学志向型」と、学習者が 主体的、積極的にクラス活動に関与することを好む「8クラス参加型」の 2 類型で ある。本調査では、各項目について、[5 : 非常によく当てはまる、4:当てはまる、 3 : 多少当てはまる、 2 : どちらかというとあまり当てはまらない、 1 ：当ては まらない、0：全く当てはまらない］の段階から 1 つ選びを回答してもらった。

表 7 学習スタイル回答の平均値

\begin{tabular}{|c|c|c|c|c|c|}
\hline No. & & N4 & N5 & 全体 & 標準偏差 \\
\hline \multicolumn{6}{|c|}{ 1. 実用型 } \\
\hline 1 & $\begin{array}{l}\text { 外国語学習は実用的であることを } \\
\text { 一番大切にする }\end{array}$ & 3.95 & 3.94 & 3.96 & 0.88 \\
\hline 9 & $\begin{array}{l}\text { 自分が日本語でコミュニケーション } \\
\text { しているところを想像する }\end{array}$ & 3.83 & 3.75 & 3.81 & 0.96 \\
\hline 19 & $\begin{array}{l}\text { 実際に使える状況がすぐに } \\
\text { 思い浮かべられる }\end{array}$ & 3.26 & 3.35 & 3.30 & 0.95 \\
\hline 21 & $\begin{array}{l}\text { 方法がどうであれ、課題を達成する } \\
\text { ことを大切にする }\end{array}$ & 3.56 & 3.60 & 3.56 & 1.08 \\
\hline 31 & 実際に使って自然に身につけていく & 3.91 & 3.86 & 3.91 & 0.81 \\
\hline 36 & $\begin{array}{l}\text { 新しいことを勉強したら、実際に } \\
\text { どのように使うのかを考える }\end{array}$ & 3.72 & 3.74 & 3.73 & 0.87 \\
\hline \multicolumn{2}{|c|}{ 平均值 } & 3.71 & 3.71 & 3.71 & \\
\hline \multicolumn{6}{|c|}{ 2. 挑戦型 } \\
\hline 4 & $\begin{array}{l}\text { 効果的な方法だと思ったら、すぐに } \\
\text { それを試してみる }\end{array}$ & 3.91 & 3.87 & 3.90 & 0.78 \\
\hline 7 & $\begin{array}{l}\text { 間違いを気にしないで話したり } \\
\text { 書いたりする }\end{array}$ & 3.61 & 3.52 & 3.60 & 1.03 \\
\hline 13 & $\begin{array}{l}\text { 必要な情報を教師、友人、本などから } \\
\text { できるだけ集める }\end{array}$ & 3.63 & 3.68 & 3.63 & 0.95 \\
\hline 14 & 今までとは違う新しいことに挑戦する & 3.49 & 3.52 & 3.50 & 0.92 \\
\hline
\end{tabular}




\begin{tabular}{|c|c|c|c|c|c|}
\hline 18 & $\begin{array}{l}\text { うくいくかどうかわからなくても、 } \\
\text { いろいろな方法を試す }\end{array}$ & 3.47 & 3.63 & 3.49 & 0.86 \\
\hline 20 & 慣れない方法でも柔軟に対応できる & 2.88 & 2.98 & 2.90 & 0.94 \\
\hline 28 & $\begin{array}{l}\text { 思いついたことは、深く考える前に } \\
\text { 言葉に出す }\end{array}$ & 2.85 & 2.84 & 2.88 & 1.07 \\
\hline 44 & $\begin{array}{l}\text { 新しい挑戦的な活動や教材の方が } \\
\text { 好きだ }\end{array}$ & 3.63 & 3.73 & 3.66 & 0.93 \\
\hline \multicolumn{2}{|c|}{ 平均值 } & 3.43 & 3.47 & 3.44 & \\
\hline \multicolumn{6}{|c|}{ 3. 感覚型 } \\
\hline 2 & $\begin{array}{l}\text { いろいろ考えるよりも直感を } \\
\text { 一番大切にする }\end{array}$ & 3.15 & 3.15 & 3.20 & 1.08 \\
\hline 10 & $\begin{array}{l}\text { 細かいことがわからなくても、 } \\
\text { 全体が大きくつかめる }\end{array}$ & 3.68 & 3.65 & 3.68 & 0.83 \\
\hline 24 & $\begin{array}{l}\text { 後で役に立つかどうかよりも、 } \\
\text { 今楽しいことを大切にする }\end{array}$ & 3.98 & 3.97 & 3.97 & 0.99 \\
\hline 29 & $\begin{array}{l}\text { 課題をする際、初めに手順を } \\
\text { 決めずにその場その場で対応する }\end{array}$ & 3.00 & 2.90 & 2.98 & 1.17 \\
\hline 32 & $\begin{array}{l}\text { 決まった言い方は、分析せずに } \\
\text { そのまま覚えてしまう }\end{array}$ & 3.28 & 3.20 & 3.31 & 1.15 \\
\hline 35 & $\begin{array}{l}\text { 詳しい説明よりも、要点を抑えた } \\
\text { 説明を求める }\end{array}$ & 3.00 & 3.09 & 3.07 & 1.07 \\
\hline \multicolumn{2}{|c|}{ 平均值 } & 3.35 & 3.33 & 3.37 & \\
\hline \multicolumn{6}{|c|}{ 4. 熟考型 } \\
\hline 3 & $\begin{array}{l}\text { 課題（作文や発表）をするときは、 } \\
\text { 準備に時間をかける }\end{array}$ & 3.83 & 3.71 & 3.79 & 0.89 \\
\hline 16 & $\begin{array}{l}\text { 課題をする際、どのような結果に } \\
\text { なるのか考えてから始める }\end{array}$ & 2.78 & 2.88 & 2.81 & 1.01 \\
\hline 26 & 目標を立てて意欲的に取り組む & 3.25 & 3.38 & 3.29 & 0.99 \\
\hline 34 & $\begin{array}{l}\text { 自分でやってみるよりも、他の人が } \\
\text { やっているのを見ている }\end{array}$ & 3.22 & 3.33 & 3.30 & 1.00 \\
\hline 37 & $\begin{array}{l}\text { 課題を始める前に、どのような } \\
\text { 手順でするかを決める }\end{array}$ & 2.89 & 2.98 & 2.90 & 1.13 \\
\hline 38 & $\begin{array}{l}\text { いろいろと考えたほうがいいと思う } \\
\text { ので、結論は時間をかけて慎重に出す }\end{array}$ & 3.35 & 3.40 & 3.34 & 0.99 \\
\hline
\end{tabular}




\begin{tabular}{|c|c|c|c|c|c|}
\hline 39 & $\begin{array}{l}\text { 目標に向かって、一歩一歩段階的に } \\
\text { 進めていく }\end{array}$ & 3.69 & 3.72 & 3.68 & 0.89 \\
\hline \multicolumn{2}{|c|}{ 平均值 } & 3.29 & 3.34 & 3.30 & \\
\hline \multicolumn{6}{|c|}{ 5. 論理型 } \\
\hline 6 & 論理的に正しいことを一番大切にする & 3.45 & 3.58 & 3.49 & 0.91 \\
\hline 8 & 1 つの正しい答えを求める & 4.01 & 3.91 & 3.96 & 0.85 \\
\hline 12 & 論理的に納得するまで考える & 3.55 & 3.33 & 3.46 & 0.93 \\
\hline 15 & $1 つ 1$ つ確実に理解していく & 3.78 & 3.74 & 3.77 & 0.81 \\
\hline 17 & $\begin{array}{l}\text { 直感に頼るよりも、細かく分析して } \\
\text { 考える }\end{array}$ & 3.04 & 3.23 & 3.08 & 1.03 \\
\hline 27 & 文法の規則に従って考える & 3.51 & 3.49 & 3.50 & 0.90 \\
\hline 30 & $\begin{array}{l}\text { あいまいな点があると、なかなか先に } \\
\text { 進めない }\end{array}$ & 3.20 & 3.14 & 3.21 & 1.09 \\
\hline \multicolumn{2}{|c|}{ 平均値 } & $\mathbf{3 . 5 0}$ & 3.49 & 3.49 & \\
\hline \multicolumn{6}{|c|}{ 6. 秩序型 } \\
\hline 5 & $\begin{array}{l}\text { 自分で規則を見つけながら } \\
\text { 学習するのが好きだ }\end{array}$ & 3.75 & 3.62 & 3.71 & 0.89 \\
\hline 11 & 具体例から規則を見つけ出そうとする & 3.93 & 3.89 & 3.90 & 0.77 \\
\hline 22 & 新しく学んだことを体系的に整理する & 3.29 & 3.40 & 3.33 & 0.99 \\
\hline 25 & 多くの具体例を集めて考える & 3.12 & 3.19 & 3.13 & 0.96 \\
\hline 33 & $\begin{array}{l}\text { 規則がわかったら、他の場合にも } \\
\text { 適用する }\end{array}$ & 3.52 & 3.47 & 3.51 & 0.97 \\
\hline \multicolumn{2}{|c|}{ 平均值 } & 3.52 & 3.51 & 3.52 & \\
\hline \multicolumn{6}{|c|}{ 7. 座学指向型 } \\
\hline 40 & $\begin{array}{l}\text { 教師が主に話し、学習者は当てられた } \\
\text { ときだけ話すスタイルがいい }\end{array}$ & 2.43 & 2.67 & 2.53 & 1.29 \\
\hline 41 & $\begin{array}{l}\text { 会話より文法を中心に勉強したほうが、 } \\
\text { 効果が高い }\end{array}$ & 2.65 & 2.84 & 2.69 & 1.10 \\
\hline 43 & $\begin{array}{l}\text { クラスの交流より、試験対策などの方が } \\
\text { 合っている }\end{array}$ & 2.68 & 2.86 & 2.75 & 1.16 \\
\hline \multicolumn{2}{|c|}{ 平均值 } & 2.59 & 2.79 & 2.66 & \\
\hline
\end{tabular}




\begin{tabular}{|l|l|c|c|c|c|}
\hline $\mathbf{8 .}$ クラス参加型 \\
\hline 42 & $\begin{array}{l}\text { クラスメートとのペアワークやロール } \\
\text { プレイなど、クラス活動が多いほうがいい }\end{array}$ & 3.53 & 3.53 & $\mathbf{3 . 5 3}$ & 1.07 \\
\hline $\begin{array}{l}\text { アクティビティが多い、 } \\
\text { 参加型のクラスが好きだ }\end{array}$ & 3.74 & 3.69 & $\mathbf{3 . 7 3}$ & 0.99 \\
\hline 平均值 & $\mathbf{3 . 6 3}$ & $\mathbf{3 . 6 1}$ & $\mathbf{3 . 6 3}$ & \\
\hline
\end{tabular}

\section{2.1 全体の傾向}

1〜6の 6 類型に大きな偏りがなく、突出した分類型はなかった。最も好まれて いるスタイルは「実用型」（3.71）で、次いで「秩序型」「論理型」「挑戦型」の順に 続き、「感覚型」「熟考型」は比較的低かったが、その差は小さく、多様な日本語 学習者像が見られる。

「外国語学習は実用的であることを一番大切にする」（3.96）、「自分が日本語で コミュニケーションしているところを想像する」(3.81)、「実際に使って自然に身 につけていく（3.91）」、「効果的な方法だと思ったら、すぐにそれを試してみる」

（3.90）、「後で役に立つかどうかよりも、今楽しいことを大切にする」（3.97）など、 実践的、挑戦的な志向がある一方、「課題（作文や発表）をするときは、準備に時間 をかける」（3.79）「1つの正しい答えを求める」（3.96）「1つ1つ確実に理解して いく」（3.77）、「具体例から規則を見つけ出そうとする」（3.90）といった数值の 高い項目からは、慎重かつ正確さを重視した学習を好む傾向も見られる。板井 (2002)が「すべての言葉や概念がわからなくてもコミュニケーションを楽しむ」 一方で、「ものごとの細部にこだわり、全体像をつかむのが苦手（板井 2002:69）」 であり相反する学習スタイルを持っていると指摘している点と共通する。

また、7 座学指向型と 8 クラス参加型を比較すると、8 の方が高い数值となった。 ただし 7 は標準偏差の值が大きく、回答の值にばらつきがあった。

\subsection{2 独学者の学習スタイルの特徵}

独学者群のみを抽出して全体平均と比較したところ、全体的には顕著な相違は 見られなかった。しかし、全体平均との比較で 0.1 以上差がある項目を抽出する と、表 8 の通り 12 項目が見つかった。12、17 は「熟考型」で独学者のほうが 低かった項目である。また、10、28、29の「挑戦型」「感覚型」の一部に高い項目 があった。しかし、これらは各分類型の一部であり、全体の傾向とは言えない。 なお、5、10、33、36 は自律学習に関連した項目でもある。 
表 8 独習者群の学習スタイルの特徵

\begin{tabular}{|c|c|c|c|}
\hline & & 全体平均 & 独学者平均 \\
\hline 1 & $\begin{array}{l}\text { 外国語学習は実用的であることを } \\
\text { 一番大切にする }\end{array}$ & 4.96 & 4.83 \\
\hline 12 & 論理的に納得するまで考える & 4.46 & 4.29 \\
\hline 17 & 直感に頼るよりも、細かく分析して考える & 4.08 & 3.93 \\
\hline 21 & $\begin{array}{l}\text { 方法がどうであれ、課題を達成することを } \\
\text { 大切にする }\end{array}$ & 4.56 & 4.39 \\
\hline 35 & 詳しい説明よりも、要点を抑えた説明を求める & 4.07 & 3.93 \\
\hline 40 & $\begin{array}{l}\text { 教師が主に話し、学習者は当てられた } \\
\text { ときだけ話すスタイルがいい }\end{array}$ & 3.53 & 3.25 \\
\hline \multicolumn{4}{|c|}{ 独学者群平均の方が 0.1 以上高かった項目 } \\
\hline & & 全体平均 & 独学者平均 \\
\hline 5 & 自分で規則を見つけながら学習するのが好きだ & 4.71 & 4.81 \\
\hline 10 & $\begin{array}{l}\text { 細かいことがわからなくても、全体が大きく } \\
\text { つかめる }\end{array}$ & 4.68 & 4.83 \\
\hline 28 & 思いついたことは、深く考える前に言葉に出す & 3.88 & 3.99 \\
\hline 29 & $\begin{array}{l}\text { 課題をする際、初めに手順を決めずに } \\
\text { その場で対応する }\end{array}$ & 3.98 & 4.09 \\
\hline 33 & 規則がわかったら、他の場合にも適用する & 4.51 & 4.62 \\
\hline 36 & $\begin{array}{l}\text { 新しいことを勉強したら、実際によ゙のように } \\
\text { 使うのかを考える }\end{array}$ & 4.73 & 4.83 \\
\hline
\end{tabular}

\section{6. まとめ}

本調査で明らかになったことでは、上達実感度では、香港の N4、N5 受験レベル の日本語学習者は受容能力の上達は、産出・やり取りよりも上達を実感している こと、独学者は「聞く」以外の能力の上達実感度が全体より低いことが分かった。 また、学習スタイルについては実用的で挑戦的な方法を好みながら、同時に規則 性、論理的分析をする傾向が見られ、クラス活動では参加型授業を好む学習者が 多いと思われる。また、機関学習者と独学者の間に顕著な相違点は見当たらず、 多様な学習スタイルが併存していると思われる。

今後、今回の結果を基に再検討し、より明確な理論・仮説に基づいた香港の 日本語学習者調査を実施したいと考えている。 


\section{参考文献}

Honey, P. \& Mumford, A. (1995). The learning styles questionnaire: Facilitator guide (3rd ed.). King of Prussia, PA: Organization Design and Development

Kolb, D.A. (1984). Experiential Learning. Englewood Cliffs, NJ: Prentice Hall

Kolb, D.A. (1999). Learning Style Inventory III. Boston, MA: Hay Group

板井美佐（2000）「中国人学習者の日本語学習に対するBELIEFS について一香港 4 大学での アンケート調查からー」『日本語教育』104 号, 69-78

板井美佐（2001）「香港における中国人学習者の日本語学習に対する動機(BF)、学習ST 及び

学習活動上の好みに関する調查一香港 4 大学機関の調查からー」『筑波大学留学生センター

日本語教育論集』第16号, 83-104

板井美佐（2002）「香港における中国人学習者の学習スタイルに関する調查」『筑波大学留学生

センター日本語教育論集』第17号, 61-79

宇田川 洋子 ・李夢娟・李澤森・劉礪志（2013）「香港の日本語能力試験受験者減少の要因を

探るーアンケート調查実施報告一」『日本學刊』第16号, 233-246

宇田川 洋子・李夢娟・李澤森・劉嘱志（2014）「香港の日本語学習者減少の要因－調査報告－」

『日本學刊』第17号, 107-120

宇田川 洋子 ・梁安玉 - 李澤森・侯清儀 - 李夢娟（2015）「香港の日本語学習者における言語

学習ビリーフ - 2014年香港日本語学習者背景調查報告一」『日本學刊』第18号, 121-133

岡田有加（2011）「学習スタイル一英語を学ぶ大学生を対象として一」『東京女子大学言語文化 研究』20,30-43

木山登茂子 - 中野貴子、周宏陽 ·上田早苗 - 望月貴子 · 蘇凱達 - 青山玲二郎（2011）「2010年

香港日本語学習者背景調査報告」『日本學刊』第14号, 176-195

瀬尾匡輝（2011）「香港の日本語生涯学習者の動機付けの変化一修正版グラウンデッド・

セオリー・アプローチを用いた分析から探るー」『日本學刊』第14号, 16-39

瀬尾匡輝（2013）「香港の民間語学学校で日本語を学習する高校生達の学びー構成主義の視点 から一」『日本學刊』第16号, 92-103

藤田裕子（2002）「日本人大学生の外国語学習スタイルとKolbのExperiential Learning Theory」

『JALT journal』Vol.24, No.2, pp.167-181

村上吉文（2018）『もう学校も先生もいらない!? SNS で外国語をマスターする《冒険者 メソッド》』ココ出版

山下直子 - 梁安玉 - 劉礪志 - 李澤森 - 侯清儀 - 李夢娟（2016）「2015年香港日本語学習者背景 調查」『日本學刊』第19号, 185-197

山下直子・梁安玉 ・ 劉礪志・李澤森・李夢娟（2017）「2016年香港の日本語学習者背景調査一 年少者と成人の学習動機一」『日本學刊』第20号, 118-124

山下直子・梁安玉・劉礪志・李澤森・李夢娟（2018）「2017年香港の日本語学習者背景調查」

『日本學刊』第21号, 182-192

国際交流基金（2015）『2015 年度日本語教育機関調査』

https://www.jpf.go.jp/j/project/japanese/survey/result/d1/survey_2015/all.pdf

(2019 年 3 月 14 日最終閲覧)

国際交流基金・電通（2016）『台湾・香港・韓国 日本語学習者調査結果』

https://drive.google.com/file/d/0B_YYwiD-_16lblRNVElULUpwS28/view

(2019 年 3 月 14 日最終閲覧) 